\title{
Incremental conductance MPPT in grid connected PV system
}

\author{
Praveen Kumar Mishra ${ }^{1}$, Prabhakar Tiwari ${ }^{2}$ \\ ${ }^{I^{*}}$ Department of Electrical Engineering, Madan Mohan Malaviya University of Technology Gorakhpur, INDIA \\ ${ }^{2}$ Department of Electrical Engineering, Madan Mohan Malaviya University of Technology Gorakhpur, INDIA \\ "Corresponding Author: e-mail: Praveen.mishra590@gmail.com, profptiwari@gmail.com
}

\begin{abstract}
PV (photovoltaic) system input is irradiation and ambient temperature. The solar radiation is varying in nature so efficiency is low of PV system. The various maximum power point tracking (MPPT) methods are used to enhance effectiveness of solar PV system. The incremental conductance(IC) algorithm is one of the MPPT algorithms which is extensively employed because, at steady state it has high tracking correctness and high productivity at quickly varying atmospheric circumstances. In this proposed system a combination of IC algorithm and integral regulator (IR) is used to obtain MPPT in PV system. This combination gives high accuracy, stable operation in PV module entire region and it also eliminate oscillations near about the peak power operating point. A 100kw PV system is design in MATLAB software 2016a version. This PV system consist proposed IC-IR algorithm to obtain maximal power operating point.
\end{abstract}

Keywords: PV module; IC; MPPT; IR; Boost converter.

DOI: http://dx.doi.org/10.4314/ijest.v13i1.21S

Cite this article as:

Mishra P.K., Tiwari P. 2021. Incremental conductance MPPT in grid connected PV system. International Journal of Engineering, Science and Technology, Vol. 13, No. 1, pp. 138-145. doi: 10.4314/ijest.v13i1.21S

Received: December 1, 2019; Accepted: February 5, 2021; Final acceptance in revised form: March 31, 2021

This paper was earlier presented at the International Conference on Energy, Environment \& Material Sciences (ICE2M), 1-3 December 2019 and substantially improved for this Special Issue. Guest Editor: Dr. Sri Niwas Singh, Professor (HAG), Department of Electrical Engineering, Indian Institute of Technology Kanpur, 208016 (U.P.) India, former Vice-Chancellor, Madan Mohan Malviya University of Technology Gorakhpur (April 2017 to July 2020).

\section{Introduction}

Day by day demand of electrical power increases very rapidly because this power is used in each sector of recent developing areas. To fulfill the demand traditional generating system is not enough because the input fuel cost is very high and these fuels are limited in nature. Renewable energy resources are widely used to produce electrical power to meet up the electric load demand. The major advantage with renewable power resources is that it is free and unlimited in nature. Solar energy is one of the renewable energy which is widely used for power generation. Solar vitality are more reliable, environment friendly and daily available renewable energy resource.

The solar system depends upon sun radiation which is varying in nature due to this solar system suffer low efficiency and high costs. To increase efficiency and overcome drawbacks, most of the power should be extracted from these systems using an algorithm named maximum power point tracking algorithms. Another method is physically tracking technique, in this process the Photovoltaic modules align orthogonal towards sun rays throughout whole day. This tracking method can be done automatically or manually. 
Various countries in world are using solar system widely to fulfill the load demand. The solar PV modules are employed for power generation from sun which is consisting of solar cell. The solar cells are fabricated of doped Si and Ge material. As the sun rays are tumble on the solar panels then the photon get the energy form rays and developed a photo current. Because of this the solar panel works as a current source. But irradiation varies with time which is show the nonlinearity of solar systems. To achieve the extreme energy from the panel the maximum power point tracking procedures are employed [1]. By using these algorithms we can improve the effectiveness of PV technique. Presently the research is going on to find out the best algorithms to attain the peak power from solar panel. These techniques increase the efficiency of solar panel.

Samimi and M.S.Zabini describe the concept of optimal size of photovoltaic system in varied climate [1].They describe how to choose the PV module according to the climate to achieve the extreme power from PV module. P.S. Revankar stated that to control the position of panel according to the direction of sun movement to achieve the maximum power in better way and by this the solar radiation are incident perpendicular to the panels [2].

The solar power generation is very important to meet the demand loads. But solar radiation is time varying is depend upon the temperature, irradiation, material by which panel is design and the future power generation is totally depend upon the solar energy. That is why many researchers gave concept and algorithms to attain the extreme vitality. The challenges of this field and new research opportunity in this area is my motive behind paper. The most widely used maximum power point tracking techniques are Perturb and Observe (P \& O) and Incremental conductance. The IC techniques are more efficient than P\&O method because IC algorithm is more accurate where the sun radiation is change very rapidly [3]. The sensors required to track MPPT in IC technique are more than $\mathrm{P} \& \mathrm{O}$ algorithm. In the perturb and observe technique the voltage cannot reached the exact peak power but it is very near to the maximal output power.

The proposed solar vitality system is used of PV arrays, dc converters, IC-IR algorithm [4], and three phase inverter. The 100kW PV array is used which is design in Matlab software. The PV arrays consist of series as well as parallel attached PV modules. The module is connected with boost converter and duty cycles of boost converter are control by IC techniques to make system more efficient and reliable. The input of module is radiation that varies with the time. To connect PV system with grid, a three phase voltage source inverter is employed to change system from DC to AC which is connected with boost converter output port. This inverter switches are control by grid side controller [5][6]. After the inverter a three phase transformer is also used to setup the voltage level and connect this system with utility grid.

\section{PV Array MPPT}

\section{A. PV array}

The solar panel single unit is solar cell. When various solar cell is connected then the solar array is build. The connection of solar cell in the Photovoltaic system are in series as well as parallel. The circuit diagram consisting of a diode, two resistances and a current source models a single diode paradigm of a solar cell. PV array is grouping of solar cells joined in parallel and series[7][8].

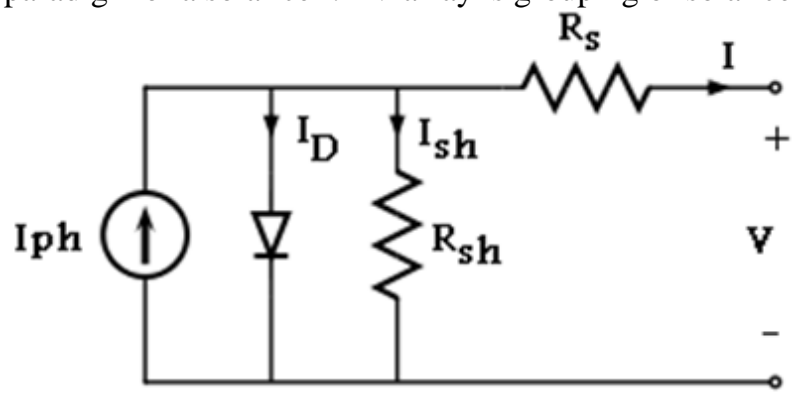

Fig.1. Single diode solar cell model

$$
\begin{gathered}
I=I_{p h}-I_{0}\left[\exp ^{\frac{e v_{d}}{K F T_{C}}}-1\right]-\frac{V_{d}}{R_{s h}} \\
I_{p h}=\left[\mu_{s c}\left(T_{c}-T_{r}\right)+I_{S C}\right]+G
\end{gathered}
$$




$$
I_{0}=I_{0 \alpha}\left(\frac{T_{C}}{T_{r}}\right)^{3} \exp \left[\frac{e V_{g}}{K F}\left(\frac{1}{T_{r}}-\frac{1}{T_{C}}\right)\right]
$$

Where $\mathrm{I}_{\mathrm{ph}}$-Photo current , $\mathrm{I}_{0}$ Dark saturation current e-Electric charge $\left(1.6 \times 10^{-19} \mathrm{C}\right), \mathrm{K}-$ Boltzmann's constant $\left(1.38 \times 10^{-23}\right)$ F-cell idealizing factor $T_{c}$-Absolute temperature, $T_{r}$ cell's Reference temperature, $V_{d}$ Diode voltage,$R_{s h}$ Parallel resistance, $R_{s}$ Series resistance , $\mathrm{I}_{\mathrm{o} \alpha}$ Cell saturation current, $\mathrm{V}_{\mathrm{oc}}$ Open circuit voltage, $\mu_{\mathrm{sc}}$ Temperature coefficient cell's short circuit current, $\mathrm{V}$ yield voltage of solar cell, I yield current of solar cell, G solar irradiation in $\mathrm{kw} / \mathrm{m} 2$. The above equation [1], [2] and [3] showed the mathematical modelling of solar cell. Form above equation it is clear that the temperature and irradiation are the determinants of solar cell output. The produced output voltage a well as current oscillates with variation in temperature along with irradiation[9][10][11].

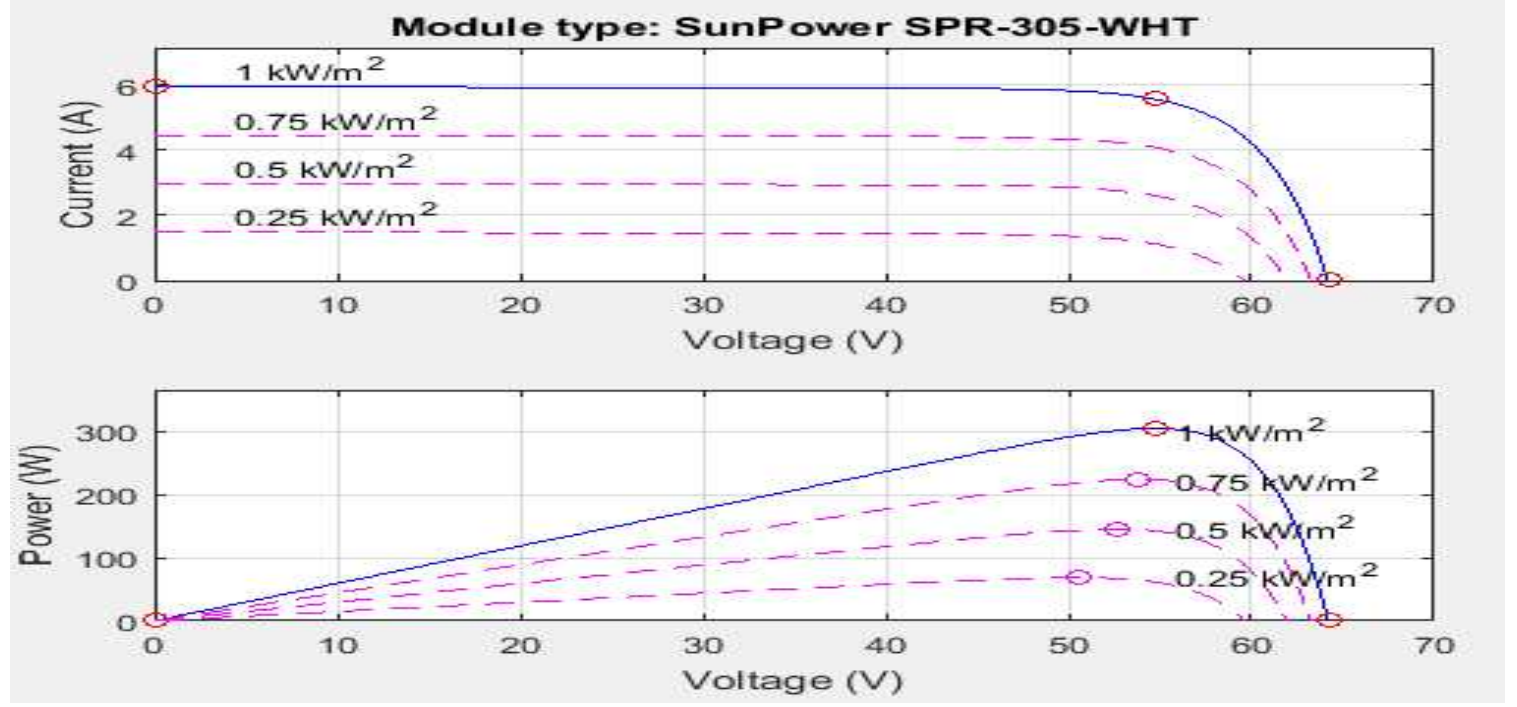

Fig.2 .I-V as well as P-V characteristics of one module at $25 \mathrm{deg}$. C
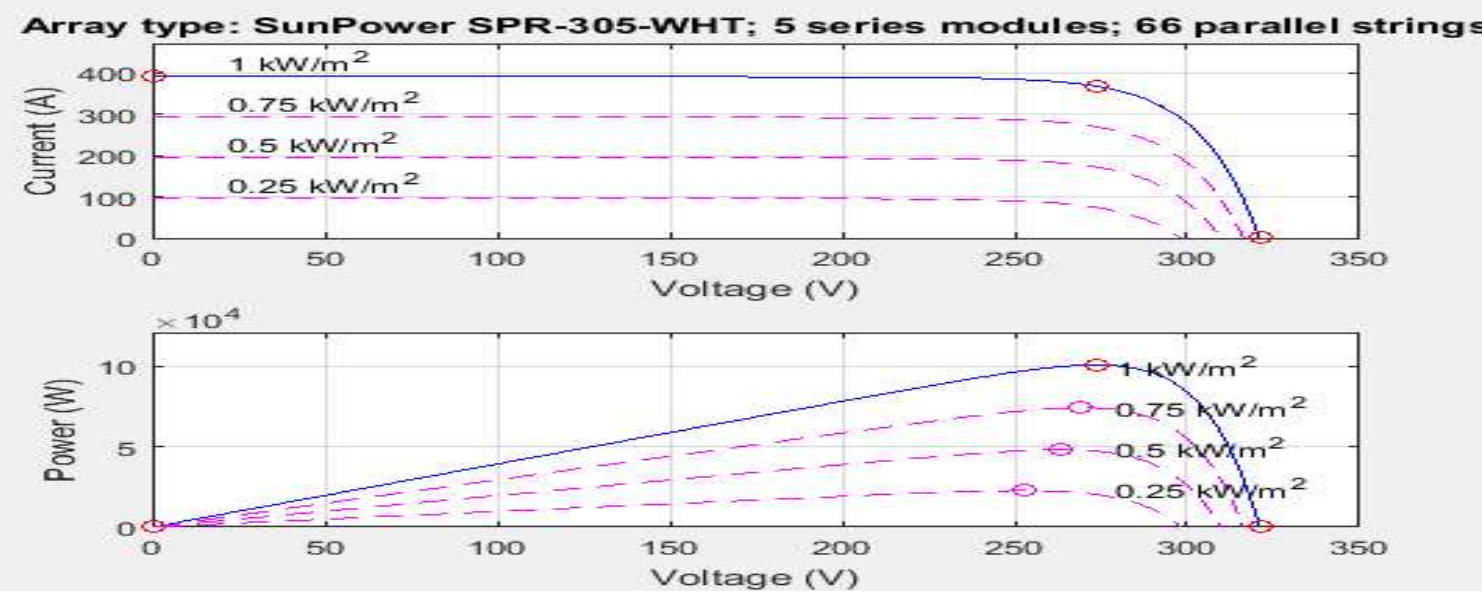

Fig.3 I-V and P-V characteristics of array at $25 \mathrm{deg}$. C

\section{Incremental conductance MPPT}

This method takes solar array amount produced voltage as well as current as input. As a consequence find out the $\frac{d l}{d V}$ along with $\frac{d P}{d V}$ and find out the incremental conductance $\frac{d l}{d V}$ by calculating the indication sign of $\frac{d P}{d V}$. Where the value of $\frac{d P}{d V}=0$ then 
algorithms knows that the extreme power point is reached. So the algorithm iterations stop and the value of voltage at the peak power point is corresponding value of functioning voltage at peak power point. This method is better than other tracking methods and this method is also used when the solar radiation is varies frequently. But it also has a disadvantage that it uses more number of sensors to perform very efficiently [12][13].

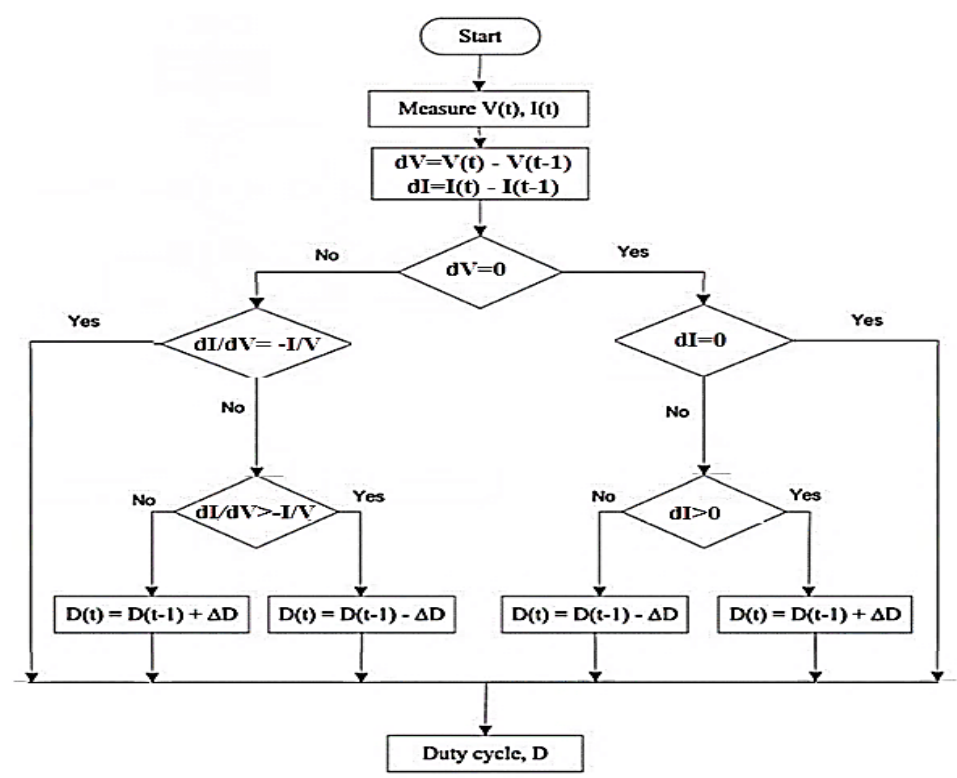

Fig.4. IC flow chart

Figure 4 present MPPT algorithm which having output is in the form of duty cycle and this duty cycle is transferred to the boost converter switch to achieved maximum vitality from the solar panel along with make the voltage constant when solar radiation is vary. As soon as the value of $\mathrm{dP} / \mathrm{dV}$ is equivalent to zero at that point maximal power point is occurs.

The modified IC method is addition of IC and integral regulator [14][15].

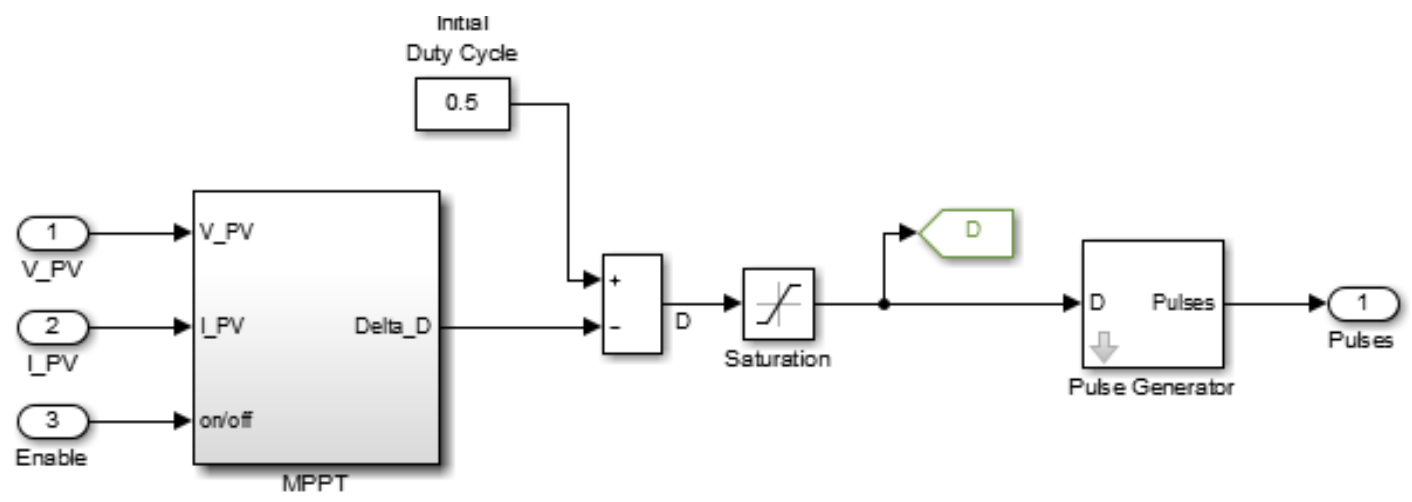

Figure 5 Simulink model of IC-IR MPPT algorithm

\section{DC-DC Boost Converter}

To increase the output power at the desired level we need a system that helps to boost the dc voltage. Boost converters are employed to achieve above stated system. The step-up process is achieved without using any transformer. The circuit of boost converter comprises of one inductor, diode along with high frequency regulator. Managing the gate pulse of switch via regulating the duty cycle we can increased the amplitude of yield voltage as compared to input voltage level [16]. 


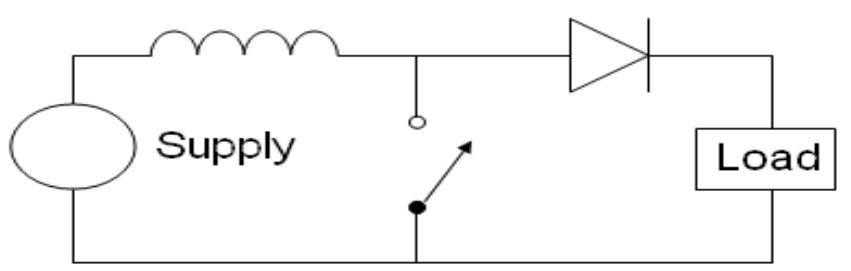

Figure 6. Boost converter

The working of boost converter id describe as follows

\section{- Charging Mode}

The inductor starts charging via supply in this mode because of this it is called charging mode. It is assumed that charging current is varying linearly but it is clear that from experiment the charging current is exponential in character. The diode opposes movement of current form source on the way to load in this mode. In charging mode only inductor is charged to a desired level by source voltage and nothing is transferred to the load.

Discharging Mode

Here diode is in forward biased along with the switch is open. This mode is called discharging mode because in this mode charged inductor starts discharging. The load is now connected with source voltage and capacitor which meets the load demand in this mode of operation in boost converter[17][18].

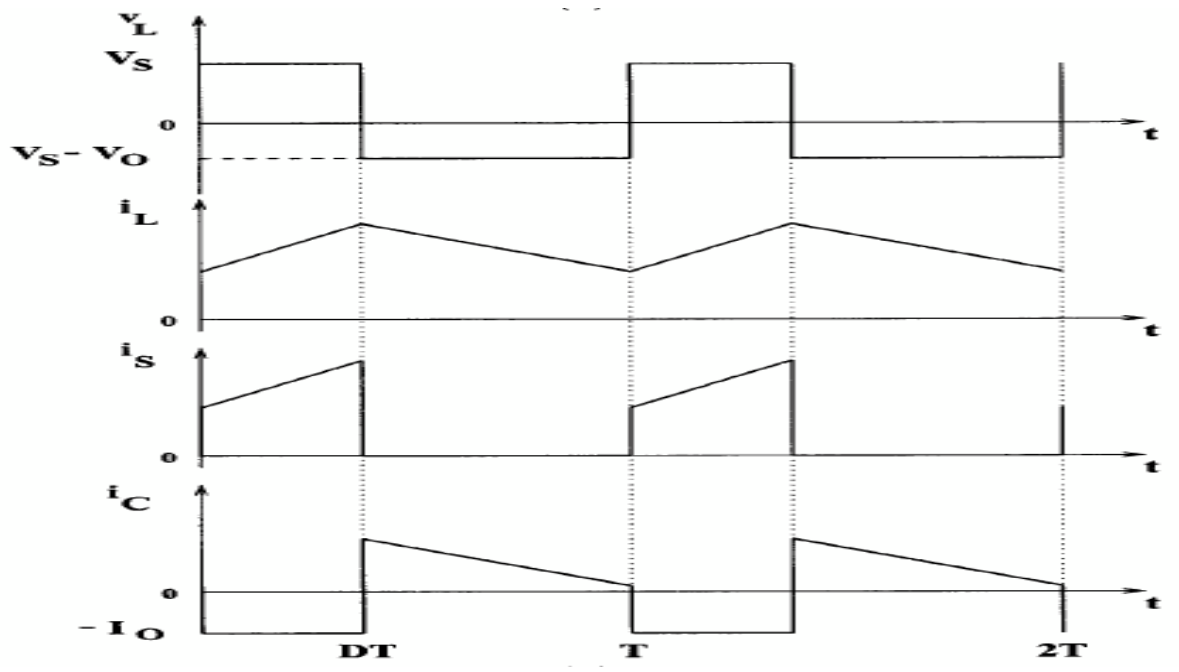

Figure 7. Waveform of boost converter

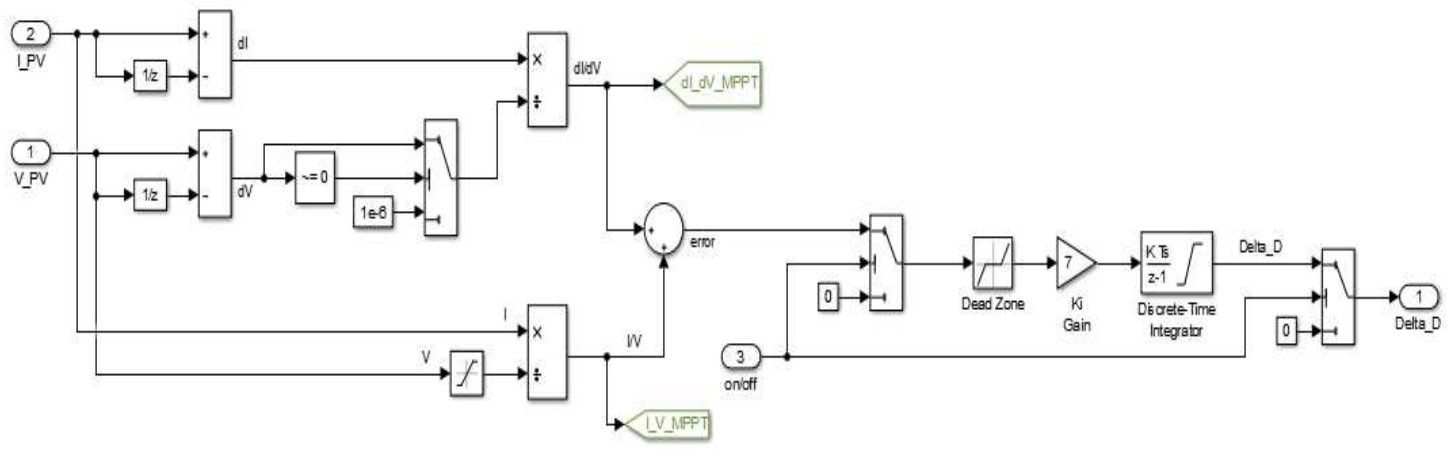

Figure 8.Mathematical modelling of IC-IR 


\section{Simulink Model and Results}

In Simulink various PV array are present and in proposed system SunPower SPR 305 WHT is consider.

Table 1. PV array parameters

\begin{tabular}{|c|c|}
\hline Parameters & Values \\
\hline $\begin{array}{c}\text { Number of cell per } \\
\text { Module }\end{array}$ & 5 \\
\hline $\begin{array}{c}\text { Number of parallel } \\
\text { string }\end{array}$ & 66.1 volts \\
\hline Voc & 54.7 volts \\
\hline Vmpp & 5.58 amps \\
\hline Impp & 1.3 \\
\hline Qd & \\
\hline
\end{tabular}

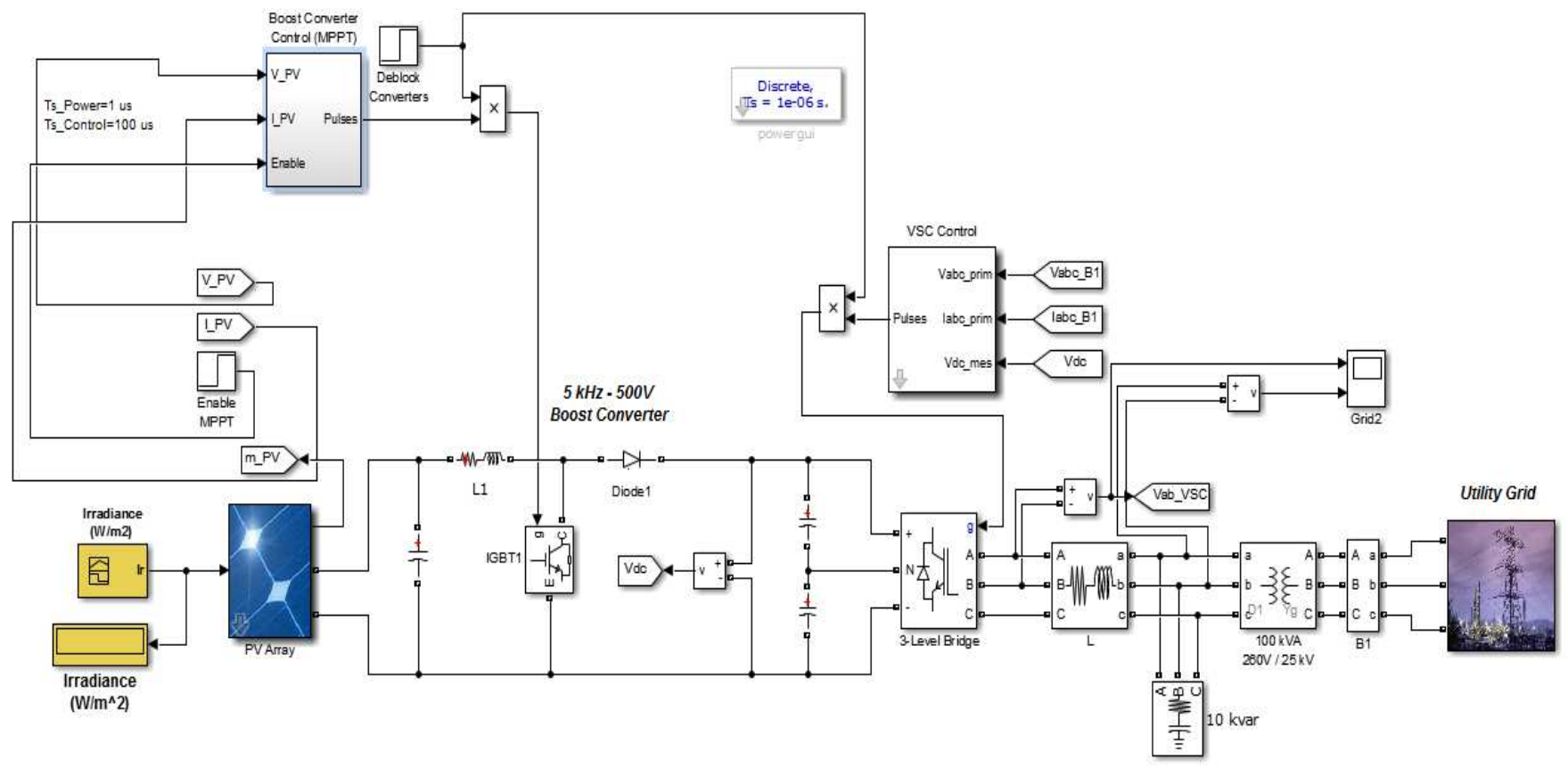

Figure 9. 100kW solar system model using IC

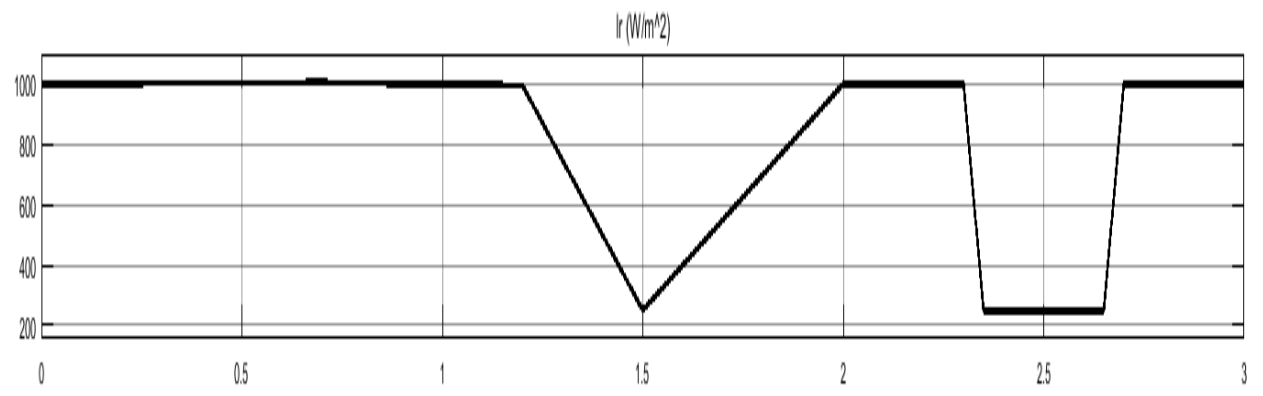

Figure.10.Solar radiation curve 


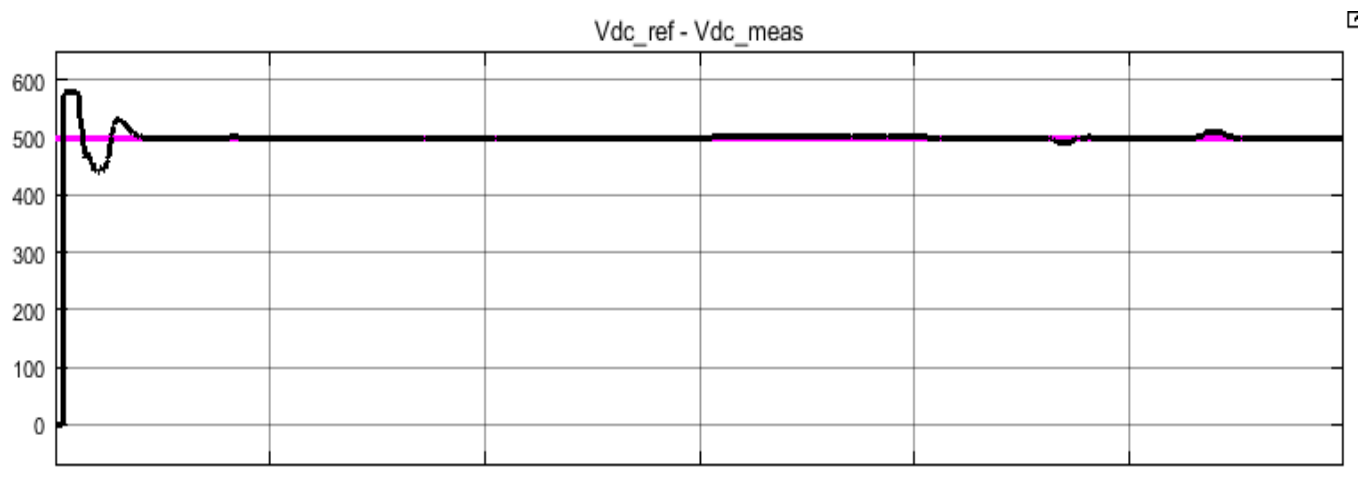

Figure.11 produced voltage of boost converter

The Figure 10 displays the curve of radiation input to PV array. The maximum value of radiation is $1000 \mathrm{~Wb} / \mathrm{m}^{2}$ and the minimum value is $200 \mathrm{~Wb} / \mathrm{m}^{2}$. The radiation varies with respect to time in between maximum and minimum value of radiation. Figure 11 displays output vitality of PV modules which shows the highest assess of array output voltage which is 260 volts and shows the yield power from boost converter which is 500 volts. So the curve of boost output voltage is constant throughout the time and no boost converter output voltage values up and down when the radiation values increases and decreases respectively. it also display curve of duty period of boost converter and duty cycles are regulated by proposed MPPT algorithm. From the graph it's clear that when the radiation is down then duty period increase and when it rises the duty cycles decreases to maintain the output constant.

Table 2. System Parameters

\begin{tabular}{|l|l|}
\hline Boost converter & Components value \\
\hline Inductance & $5 \mathrm{mH}$ \\
\hline Capacitor & $12000 \mathrm{mF}$ \\
\hline Transformer rating & Components value \\
\hline R1,R2 & $1 \mathrm{mOhm}$ \\
\hline L1,L2 & $3 \mathrm{mH}$ \\
\hline Primary voltage V1 & 260 volt \\
\hline Secondary voltage V2 & $25 \mathrm{kV}$ \\
\hline Nominal Power & $100 \mathrm{kVA}$ \\
\hline
\end{tabular}

Table 3 Output of proposed system

\begin{tabular}{|l|l|}
\hline Parameters & Value \\
\hline Solar array output voltage & 260 volts \\
\hline Boost converter output & 500 volts \\
\hline Modulation Index & 0.85 \\
\hline
\end{tabular}

\section{Conclusions}

Here In this paper, a modified incremental conductance MPPT algorithm technique has been designed and simulation done to find the results using Matlab/Simulink. This modified MPPT algorithm is capable to increase steady state and dynamic operation of PV system. It enable us to extract maximum energy from solar radiation and provide stable and efficient power supply. The above results stated that proposed MPPT algorithm can be effective in tracking maximum amount of radiation and also efficiently provides maximum power for PV array. Moreover this proposed MPPT algorithm facilitated us with maximum power at low cost and least power losses. 


\section{References}

[1] Samimi,J.E.A Soleimani and M.S.Zabini,Optimal size of photovoltaic system in varied climate.Solar Energy 1997.60(2):p.97-107.

[2] P.S.Revankar,W.Z.GandhareandA.G.ThosarGovernmentCollegeofEngineering, Aurangabad, "Maximum Power PointTracking for PVSystemsUsing MATLAB/SIMULINK",2010 SecondInternational Conference onMachineLearningand Computing

[3] J. J. Schoeman and J. D. Wyk, “A simplified maximal power controller for terrestrial photovoltaic panel arrays," in Proc. 13th Annu. IEEE Power Electron. Spec. Conf., 1982, pp. 361-367.

[4] M. A. S. Masoum, H. Dehbonei, and E. F. Fuchs, "Theoretical and exper-imental analyses of photovoltaic systems with voltage- and current-based maximum power-point tracking," IEEE Trans. Energy Convers., vol. 17, no. 4, pp. 514-522, Dec. 2002.

[5] N. Femia, G. Petrone, G. Spagnuolo, and M. Vitelli, "Optimization of per-turb and observe maximum power point tracking method," IEEE Trans. Power Electron., vol. 20, no. 4, pp. 963-973, Jul. 2005.

[6] D. Sera, T. Kerekes, R. Teodorescu, and F. Blaabjerg, "Improved MPPT method for rapidly changing environmental conditions," in Proc. IEEE ISIE, 2006, pp. 1420-1425.

[7] T. Esram and P. L. Chapman, "Comparison of photovoltaic array max- imum power point tracking techniques," IEEE Trans. Energy Convers., vol. 22, no. 2, pp. 439-449, Jun. 2007.

[8] K. H. Hussein, I. Muta, T. Hoshino, and M. Osakada, "Maximum pho- tovoltaic power tracking: An algorithm for rapidly changing atmospheric conditions," Proc. Inst. Electr. Eng.-Generation, Transmission Distrib., vol. 142, no. 1, pp. 59-64, Jan. 1995.

[9] C. K. Sao and P. W. Lehn, "Control and power management of converter fed MicroGrids," IEEE Trans. Power Syst., vol. 23, no. 3, pp. 1088-1098. Aug. 2008.I.

[10] Manisha Joshi, Prof. Dr. Mrs. G. A. Vaidya, "Modeling and Simulation of Single Phase Grid Connected Solar Photovoltaic System" 2014 Annual IEEE India Conference (INDICON), June 2014, pp. 1-6.

[11] M. Adly, M. Ibrahim, and H. El Sherif, "Comprehensive study of improved energy generation maximization techniques for photovoltaic systems," in Proc. IEEE Asia- Pacific Power and Energy Engineering Conf. (APPEEC), pp. 1-5, March 2012.

[12] G.M.S. Azevedo, M.C. Cavalcanti, K.C, Oliveria, F.A.S.Neves and Z.D. Lins, "Evaluation of maximum power tracking methods for grid connected photovoltaic systems", in Proc. IEEE Power Electronics Specialists Conf., 2008, pp.1456-1462.

[13] Ho, B.M.T., and Chung, H.S.-H.: 'An integrated inverter with maximum power tracking for grid-connected PV systems', IEEE Trans. Power Electron., 2005, 20, (4), pp. 953-962

[14] Solodovnik, E.V., Liu, S., and Dougal, R.A.: 'Power controller design for maximum power tracking in solar installations', IEEE Trans. Power Electron., 2004, 19, (5), pp. 1295-1304

[15] Kjaer, S.B., Pedersen, J.K., and Blaabjerg, F.: 'A review of single-phase grid-connected inverters for photovoltaic modules,', IEEE Trans. Ind. Appl., 2005, 41, (5), pp. 1292-1306

[16] Z. Yan, L. Fei, Y. Jinjun, and D. Shanxu, "Study on realizing MPPT by improved incremental conductance method with variable step-size," in Proc. IEEE ICIEA, Jun. 2008, pp. 547-550

[17] F. M. González-Longatt, "Model of photovoltaic module in Matlab," in 2do congreso iberoamericano de estudiantes de ingenierıacute;a eléc- trica, electrónica y computación, ii cibelec, 2005, pp. 1-5.

[18] B. Liu, S. Duan, F. Liu, and P. Xu, "Analysis and improvement of max- imum power point tracking algorithm based on incremental conductance method for photovoltaic array," in Proc. IEEE PEDS, 2007, pp. 637-641.

\section{Biographical notes}

Praveen Kumar Mishra is a M.Tech Student in the Department ofElectrical Engineering, Madan Mohan Malaviya University of Technology Gorakhpur, India.

Prabhakar Tiwari received M. Tech. From Indian Institute of Technology Delhi, India in 1999, and Ph.D. from JMI, Central University New Delhi, Power System Pricing, respectively. He is an Associate Professor, Department of Electrical Engineering Madan Mohan Malaviya University of Technology, Gorakhpur, Uttar Pradesh. He is a Fellow of IE (India), Fellow of IETE (India), and senior member of IEEE. 